\title{
Quantification of Agrobacterium vitis from Grapevine Nursery Stock and Vineyard Soil using Droplet Digital PCR
}

\author{
Tanja M. Voegel ${ }^{\dagger}$ and Louise M. Nelson, Department of Biology, University of British Columbia Okanagan, Kelowna, BC, V1V 1V7, \\ Canada
}

\begin{abstract}
Current detection methodologies for Agrobacterium vitis, causing crown gall of grapevines, are time intensive and lack the ability to quantify pathogen abundance in nursery stock and soil. Information on pathogen abundance is a key component to develop management strategies. The aim of this study was to develop a rapid and sensitive quantification assay for grapevine nursery stock and vineyard soil via droplet digital polymerase chain reaction targeting the virA gene. DNA isolated from roots of dormant grapevines originating from nurseries in Germany, California, and Ontario were tested for virA abundance. Bacterial

numbers varied with grapevine origin; plants from California had the highest numbers. In addition, rhizosphere soil from two vineyards in the Okanagan valley in British Columbia was tested over a growing season. Sampling time during the season did not affect virA gene abundance. The older vineyard had higher soil $A$. vitis populations than the younger vineyard. The assay developed here has potential for use in national clean plant programs to prevent import of infected grapevine nursery stock and to test vineyard soil for abundance of the pathogen before planting.
\end{abstract}

Crown gall of grapevines, caused by the gram-negative bacterium Agrobacterium vitis (Ophel and Kerr 1990), is an economically important disease in grape-growing regions with a continental climate, particularly in those where winter freezing occurs. The pathogen is introduced into the vineyard through contaminated grapevine nursery stock or infects wounded grapevine roots through soil harboring the bacterium (Burr et al. 1998; Süle et al. 1995). Additionally, a recent study has shown wild grapevines as a significant reservoir of inoculum (Orel et al. 2017). Wound sites in trunks and canes caused by winter freezing, mechanical injuries, or poor grafting attract $A$. vitis cells and induce gall formation (Burr et al. 1998). Crown gall significantly reduces plant vigor and the disease may cause partial or complete vine death, especially in young vines (Schroth et al. 1988). Economic losses of US\$46,500 per 0.4-ha vineyard over a 6-year period were estimated to be caused by crown gall in Pennsylvania (Stewart and Wenner 2004).

To date, management strategies are mainly based on cultural practices, including planting of less susceptible rootstocks and cultivars, hilling up to cover graft unions with soil to minimize winter injury, training of multiple trunks per vine, or efforts to prevent soil freezing (Burr et al. 1998). However, the most successful strategy is disease prevention by planting healthy grapevine nursery stock into healthy soil (Johnson et al. 2013). A hallmark of A. vitis biology is its systemic survival in symptomless vines, resulting in difficulty in producing healthy grapevine stock (Burr et al. 1998). Hot water treatment is applied on some occasions by nurseries before the plants are sold to growers (Burr et al. 1989, 1996). However, this methodology only reduces but does not eliminate A. vitis (Burr et al. 1996). To ensure that grapevine stock is pathogen free, it is important to develop sensitive technologies to detect and quantify $A$. vitis before establishing a new vineyard. Existing indexing methodologies involving collection of bleeding sap or plating on semiselective medium are time intensive,

${ }^{\dagger}$ Corresponding author: Tanja M. Voegel; E-mail: tanja.voegel@ubc.ca

Funding: Funding for this project was provided by the Natural Sciences and Engineering Research Council of Canada-Engage (grants EGP 491650-15 and EGP2 508680-17), with the British Columbia Wine Grape Council as industry partner.

Accepted for publication 23 April 2018.

C 2018 The American Phytopathological Society not sensitive enough, or prone to contamination (Bazzi et al. 1987; Bishop et al. 1989; Lehoczky 1971). Newer polymerase chain reaction (PCR)-based methodologies have improved indexing of grapevine stock (Bini et al. 2008; Eastwell et al. 1995; Peduto et al. 2010; Puławska and Sobiczewski 2005). A recently developed magnetic capture hybridization $(\mathrm{MCH})$ technology showed increased detection sensitivity compared with earlier PCR-based methods because of the removal of PCR inhibitors and the use of quantitative real-time PCR (qPCR) (Johnson et al. 2013). The MCH method was able to detect A. vitis in naturally infected grapevines, green shoots, and grape buds and on the surface of grape leaves (Johnson et al. 2016). However, $\mathrm{MCH}$ includes an enrichment step, where bacteria are grown in a broth before DNA extraction and qPCR are conducted. This enrichment step prevents absolute quantification of A. vitis. Information on A. vitis abundance in grapevines is needed to increase our understanding of pathogen biology and to determine an A. vitis density threshold at which crown gall disease will occur.

Even when healthy grapevines are used for replanting or establishing a new vineyard, $A$. vitis residing in soil can infect healthy plant roots because the bacteria survive on infected, decaying roots in soil for at least 2 years after removal of diseased grapevines (Bishop et al. 1988; Burr et al. 1987, 1995; Süle et al. 1995). To achieve the goal of planting healthy nursery stock into healthy soil, sensitive soil quantification methodologies are needed in addition to methods for testing of nursery stock.

Droplet digital PCR (ddPCR) is a recently developed technology for absolute nucleic acid quantification (Hindson et al. 2011). The nucleic acids in a sample are partitioned into approximately 20,000 droplets that support PCR amplification of single template molecules. The DNA binding dye included in the supermix is used to distinguish positive droplets (amplification of target molecule) from negative droplets (no target molecule present) via automated droplet flow cytometry. The number of target molecules in the sample can be calculated using Poisson statistics (Hindson et al. 2011). Advantages over other quantitative technologies such as qPCR are the possibility for absolute quantification without the need of standards, the insignificance of primer efficiencies, and the increased assay sensitivity due to dilution of PCR inhibitors in the droplets. Accordingly, the objective of this study was to develop a rapid and sensitive ddPCR assay to quantify A. vitis populations in grapevine nursery stock and vineyard soil. The assay was used to determine A. vitis abundance in (i) planting material originating from nurseries in Germany, California (United States), and Ontario (Canada) and in (ii) soils of two vineyards in the Okanagan Valley, British Columbia (Canada) over a growing season. 


\section{Materials and Methods}

ddPCR. ddPCR was performed on a Bio-Rad QX200 system using an EvaGreen assay (Bio-Rad, Hercules, CA, USA). The PCR contained $11 \mu \mathrm{l}$ of QX200 supermix (Bio-Rad), $1 \mu$ l of each $2.2 \mu \mathrm{M}$ primer solution (final concentration $100 \mathrm{nM}$ for each primer), and $2 \mu \mathrm{l}$ of template in a final volume of $22 \mu \mathrm{l}$. The PCR were mixed and centrifuged briefly, and $20 \mu \mathrm{l}$ was transferred into the sample well of a DG8 cartridge (Bio-Rad). After adding $70 \mu \mathrm{l}$ of QX200 droplet generation oil (Bio-Rad) into the oil wells, the cartridge was covered using a DG8 gasket, and droplets were generated using the QX200 droplet generator (Bio-Rad). Droplets were carefully transferred into PCR plates using a multichannel pipette and the plate was sealed using PCR plate heat seal foil and the PX1 PCR plate sealer (Bio-Rad). PCR was performed in a C1000 touch thermal cycler (Bio-Rad) using the following PCR program: $95^{\circ} \mathrm{C}$ for $5 \mathrm{~min}, 40$ cycles of $95^{\circ} \mathrm{C}$ for $30 \mathrm{~s}$, optimal annealing temperature $\left({ }^{\circ} \mathrm{C}\right)$ for $1.20 \mathrm{~min}, 4^{\circ} \mathrm{C}$ for $5 \mathrm{~min}, 90^{\circ} \mathrm{C}$ for $5 \mathrm{~min}$, and hold at $4^{\circ} \mathrm{C}$; ramp rate was $2.5^{\circ} \mathrm{C} / \mathrm{s}$. PCR plates were transferred into a QX200 droplet reader (Bio-Rad) and reads were analyzed using QuantaSoft software (Bio-Rad).

ddPCR assay development. A thermal-gradient PCR experiment was conducted to establish the optimal annealing temperature for each primer pair: virA, pehA (Eastwell et al. 1995), and virD2 (Johnson et al. 2013). A. vitis strain CG47 (Eastwell et al. 1995) was grown on Luria-Bertani (LB) (Bertani 1951) plates at $28^{\circ} \mathrm{C}$ for 2 days. DNA was extracted using the E.Z.N.A. bacterial DNA kit (Omega Bio-tek, Norcross, GA, USA) and $2 \mu$ of a 1:1,000 dilution was used as template. Temperatures tested ranged from 53.5 to $60^{\circ} \mathrm{C}$. Primer pairs used were virAfor/virArev, pehAfor/pehArev (Eastwell et al. 1995), and virD2.Forl/virD2.Rev1 (Johnson et al. 2013).

Detection limit. A. vitis strain CG47 DNA (Eastwell et al. 1995) was extracted as above, the concentration was determined by Nanodrop spectrophotometry (Thermo Scientific, Wilmington, DE, USA), and a 10 -fold serial dilution of 1 to $0.00001 \mathrm{ng} / \mu \mathrm{l}$ was prepared. Then, $1 \mu$ l of each dilution was used as template for ddPCR and the experiment was repeated three times.

To assess the detection limit in grapevines, A. vitis strain CG47 (Eastwell et al. 1995) was grown on LB plates at $28^{\circ} \mathrm{C}$ for 2 days. Bacteria were adjusted to $10^{8} \mathrm{CFU} / \mathrm{ml}$ in $1 \times$ sterile phosphatebuffered saline (PBS), pH 6.8. Roots of Riesling grapevine seedlings were cut into $2-\mathrm{mm}$ pieces using pruning shears and $0.3 \mathrm{~g}$ was spiked with $100 \mu \mathrm{l}$ of a serial dilution of $A$. vitis in $1 \times \operatorname{PBS}\left(10^{7}\right.$ to $\left.10^{1} \mathrm{CFU} / \mathrm{ml}\right)$ or $1 \times$ PBS only as negative control. DNA was isolated using the MoBio Powersoil DNA extraction kit, according to the manufacturer's instructions (MoBio, Carlsbad, CA, USA). DNA was eluted in $100 \mu$ l of elution buffer provided with the kit. Concentrations and absorbance ratios were determined by Nanodrop spectrophotometry (Thermo Scientific, Wilmington, DE, USA). Aliquots of nucleic acids were stored at $-20^{\circ} \mathrm{C}$ until use. As template for ddPCR, $2 \mu \mathrm{l}$ was used, and the experiment was repeated three times.
Because A. vitis is host specific to grape, cherry orchard soil was used to assess the detection limit. Soil was sterilized by microwaving for $3 \mathrm{~min}$, mixed, and microwaved again for $3 \mathrm{~min}$. Soil was stored overnight at $4{ }^{\circ} \mathrm{C}$ and the microwaving was repeated as above. Soil $(0.25 \mathrm{~g})$ was spiked with $100 \mu \mathrm{l}$ of a serial dilution of $A$. vitis in $1 \times \mathrm{PBS}\left(10^{7}\right.$ to $\left.10^{1} \mathrm{CFU} / \mathrm{ml}\right)$ or $1 \times \mathrm{PBS}$ only as negative control. DNA was extracted and processed as above and the experiment was repeated three times.

Nursery plant material, experimental vineyards, and DNA extraction. Ready-to-plant dormant rooted grapevines from commercial nurseries were donated by local wineries in the Okanagan region in Canada in spring 2016 and stored in a cold room at $4{ }^{\circ} \mathrm{C}$ until use. Information on origin, scion, and rootstock cultivars of dormant vines is listed in Table 1. In total, 45 grapevines (5 plants per cultivar from each nursery) were evaluated. For each grapevine, four primary roots were separated from the plant and cut at the top, middle, and end into 2-mm pieces using pruning shears that were cleaned with $70 \%$ ethanol between samples. Cherry tree roots were used as negative control. DNA was isolated from $0.3 \mathrm{~g}$ of root tissue per sample using the MoBio Powersoil DNA extraction kit, as described above. Dormant rooted grapevine stock from the same shipments as the plants used for ddPCR analysis were planted in spring 2016 by the respective winery. In spring 2017, four vineyards where the vines were not used as replants or where the tested nursery stock had the highest concentrations of $A$. vitis were monitored for crown gall symptoms by visually rating 90 plants.

Both vineyards used for sampling of soil throughout the 2017 growing season are located in Kelowna, British Columbia (Canada) and are owned and managed by the same winery. Details of the vineyards are listed in Table 2. Vineyard soil was sampled five times over the growing season according to growth stages of the grapevines: 2 May (bud break), 20 June (bloom), 6 July (pea-size berries), 28 August (veraison), and 10 October (after harvest). Six vines per site with visible crown gall symptoms were randomly chosen and the same vines were sampled each time. Soil was sampled from underneath the dripline $20 \mathrm{~cm}$ away from the trunk using a $30-\mathrm{cm}$ soil probe. One soil core from the right and one from the left side of the trunk were combined. Three samples taken from adjacent grasslands were

Table 2. Vineyards used in the study

\begin{tabular}{lll}
\hline Variables & Vineyard 1 & Vineyard 2 \\
\hline Cultivar & Chardonnay & Chardonnay \\
Rootstock & $101-14$ & $3309 \mathrm{c}$ \\
Nursery & Nursery e & Nursery e \\
Year planted & 2012 & 2014 \\
Age at time of sampling & 5 years & 3 years \\
Percentage sand/silt/clay & $26 / 43 / 31$ & $67 / 30 / 3$ \\
Previous land use & Apple orchard & Grassland \\
\hline
\end{tabular}

Table 1. Origin, cultivar, and droplet digital polymerase chain reaction (ddPCR) results of tested grapevine nursery stock

\begin{tabular}{|c|c|c|c|c|c|c|}
\hline Sample ID & Origin $^{x}$ & Nursery & Cultivar & Rootstock & virA copies/0.3 g of roots $( \pm S D)^{y}$ & Gall occurrence $(\%)^{\mathrm{z}}$ \\
\hline 1 & Canada & $\mathrm{a}$ & Merlot & 3309 & $305( \pm 364) d$ & na \\
\hline 2 & Canada & $\mathrm{a}$ & Pinot Noir & 3309 & $306( \pm 144) \mathrm{cd}$ & 0 \\
\hline 3 & Canada & $\mathrm{a}$ & Pinot Gris & 3309 & $932( \pm 456) \mathrm{cd}$ & na \\
\hline 4 & United States & $\mathrm{b}$ & Cabernet Sauvignon & 3309 & $17,208( \pm 11,366) b$ & 1 \\
\hline 5 & Canada & c & Chardonnay & 3309 & $885( \pm 824) \mathrm{cd}$ & na \\
\hline 6 & Germany & $\mathrm{d}$ & Riesling & 3309 & $9,430( \pm 18,967) \mathrm{c}$ & na \\
\hline 7 & Canada & a & Pinot Noir & $\mathrm{SO} 4$ & $463( \pm 466) \mathrm{cd}$ & na \\
\hline 8 & United States & $\mathrm{e}$ & Chardonnay & 3309 & $259,656( \pm 71,434) \mathrm{a}$ & 33 \\
\hline 9 & United States & $\mathrm{f}$ & Syrah & $101-14$ & $100,427( \pm 19,516) \mathrm{a}$ & 0 \\
\hline
\end{tabular}

${ }^{x}$ Nursery stock originating from Canada and the United States were received from Ontario and California, respectively.

y Numbers are means $(n=5)$ followed by the standard deviation (SD). Different letters indicate significant differences between samples by Tukey's studentized range (honestly significant difference) test $(P<0.05)$.

${ }^{\mathrm{z}}$ Vineyards with planted nursery stock from the same shipment as samples used for ddPCR were visited 1 year after planting and 90 plants monitored for gall development; na = not applicable (vineyards were not monitored for gall development). 
collected as controls. The intact soil cores were transported to the laboratory and grapevine roots with attached rhizosphere soil was removed with tweezers. After air drying, rhizosphere soil was separated from roots and $0.25 \mathrm{~g}$ was used for DNA extraction using the MoBio Powersoil DNA extraction kit, as described above. The leftover soil was sieved through a $20-\mathrm{mm}$ sieve and sent to the British Columbia Ministry of Environment, Analytical Chemistry Laboratory, Victoria for determination of $\mathrm{pH}\left(1: 1\right.$ in $\left.\mathrm{H}_{2} \mathrm{O}\right)$, total carbon and nitrogen $(\mathrm{C} / \mathrm{N}$ ratio), and particle size using standard protocols of the facility.

Statistical analysis. All data were tested for normality using the Shapiro-Wilk test, log transformed, and analyzed by analysis of variance using R. Tukey's honestly significant difference and Welch's $t$ test were used for mean separation of nursery stock and soil data, respectively.

\section{Results}

ddPCR, detection, and quantification limit. Specificity of the virA, pehA, and virD2 primers for $A$. vitis has been shown in earlier studies (Eastwell et al. 1995, Johnson et al. 2013). The optimal annealing temperature for primer pair virA using pure culture $A$. vitis CG47 DNA in ddPCR was established at $59.6^{\circ} \mathrm{C}$, which resulted in the best separation between positive and negative droplets and in the highest number of positive droplets (Fig. 1). PehA primers (Eastwell et al. 1995) generated a product at annealing temperatures of 56 to $60^{\circ} \mathrm{C}$ (Fig. 2). Primers targeting the virD2 gene (Johnson et al. 2013) also produced positive droplets; however, rain caused difficulties in efficiently separating positive from negative droplets in ddPCR, indicating the need for further optimization if targeting of the virD2 gene is required (data not shown).

The detection limit of pure culture A. vitis strain CG47 DNA was $0.1 \mathrm{pg} / \mu \mathrm{l}$, with a detection frequency of $100 \%$ (Fig. 3). There were no positive droplets (no detection) in the no-template control. The quantification limit for $A$. vitis in spiked grapevine roots and soil was determined by plotting the log value of ddPCR data against bacterial numbers from the dilution series (Fig. 4). The lower limit of the linear range of the assay determined the quantification limit, which was 1,000 A. vitis cells $\left(R^{2}=0.99\right)$ for both. The limit of detection for both was 100 cells, which were detected with a frequency of $66 \%$ for soil and $33 \%$ for root samples.

Quantification of $\boldsymbol{A}$. vitis in nursery stock. Nurseries had a significant effect on $A$. vitis abundance in roots $(P<0.001$; Table 1$)$. Plants originating from Ontario nurseries had fewer virA copies (305 to 932 copies per $0.3 \mathrm{~g}$ of roots) compared with plants from the three Californian nurseries (over 17,000 copies per $0.3 \mathrm{~g}$ of roots). There was considerable copy number variation among replicates, indicated by the high standard deviation among samples from the same nursery. A Riesling sample from Germany had 10,278 copies per $0.3 \mathrm{~g}$ of root and a different clone from the same nursery had a 3.6 times higher concentration. Cherry root samples served as a negative control and showed no positive droplets. Grapevine nursery stock from the same shipments as the test samples used for ddPCR was planted in spring 2016 in the Okanagan Valley (British Columbia). The following winter was cold, with minimum air temperatures frequently reaching less than $-20^{\circ} \mathrm{C}$ during December 2016 and January 2017, conducive for disease development. In spring 2017, 1 year after planting, four vineyards were monitored for gall development (Table 1). Sample ID 8 had the highest $A$. vitis abundance, and 30 of 90 rated plants in the vineyard from the same shipment had visible galls.

Quantification of $\boldsymbol{A}$. vitis in vineyard soil. $A$. vitis abundance in vineyard 1 ranged from 1,244 to 64,224 copies/g of soil and, in vineyard 2, from 85 to 5,827 copies/g of soil (Fig. 5, Table 3). Grapevine growth stage did not affect $A$. vitis abundance when data were combined $(P=0.059)$. Vineyard had a significant effect; $A$. vitis abundance was, on average, six times higher at vineyard 1 compared with vineyard $2(P<0.001)$. Average soil $\mathrm{pH}$ was 7.4 for vineyard 1 , which was higher than the average soil $\mathrm{pH}$ of 6.9 for vineyard 2 $(P<0.001)$, but $\mathrm{pH}$ did not affect $A$. vitis abundance $(P=0.27)$. On the other hand, the $\mathrm{C} / \mathrm{N}$ ratio significantly affected bacterial abundance $(P<0.001)$ and was higher in vineyard $2(\mathrm{C} / \mathrm{N}=14.87)$ compared with vineyard $1(\mathrm{C} / \mathrm{N}=12)(P<0.001)$

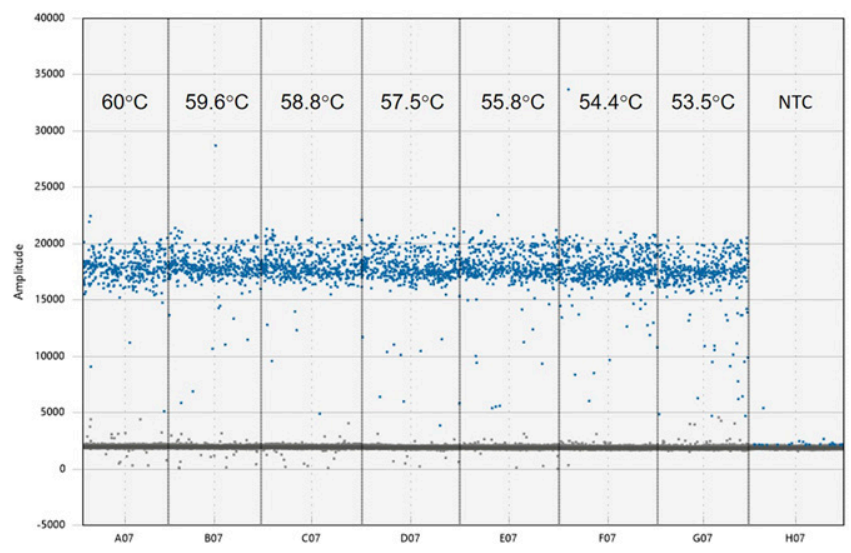

Fig. 2. A gradient droplet digital polymerase chain reaction assay was used to determine the optimal annealing temperature for the pehA primer pair using pure culture Agrobacterium vitis strain CG47 DNA. Separation between positive (higher amplitude) and negative droplets (lower amplitude baseline) was equal at all of the temperatures tested. NTC $=$ negative template control.

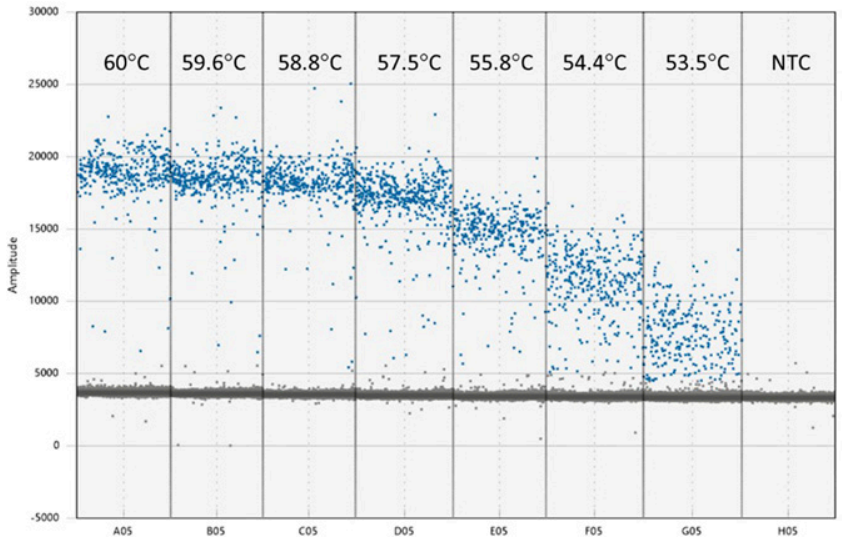

Fig. 1. A gradient droplet digital polymerase chain reaction assay was used to determine the optimal annealing temperature for the virA primer pair using pure culture Agrobacterium vitis strain CG47 DNA. A temperature of $59.6^{\circ} \mathrm{C}$ resulted in the best separation between positive (higher amplitude) and negative droplets (lower amplitude baseline). NTC = negative template control.

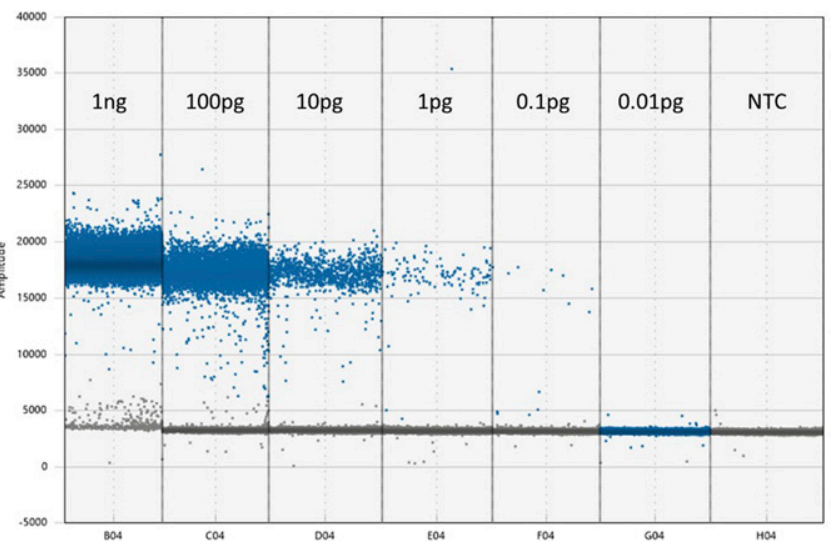

Fig. 3. The detection limit of the virA droplet digital polymerase chain reaction assay was determined using a 10-fold serial dilution of Agrobacterium vitis strain CG47 DNA. A concentration of $0.1 \mathrm{pg} / \mu \mathrm{l}$ was detected with a frequency of $100 \%$. The experiment was repeated three times. NTC = negative template control. 


\section{Discussion}

A ddPCR assay to allow for sensitive absolute quantification of the plant pathogen A. vitis population in roots of grapevine nursery stock and vineyard soil was developed. For the purpose of this study, targeting of the virA gene was chosen because the VirA/VirG twocomponent regulatory system is located on the tumor-inducing plasmid and is essential for virulence (Stachel and Zambryski 1986; Wise and Binns 2016). However, the virA primers do not amplify a product from a subset of tumorigenic $A$. vitis strains that carry vitopine-type plasmids (Burr and Otten 1999; Otten et al. 1996). Therefore, other primers such as primers targeting pehA were successfully tested to allow for adaptation of the assay. PehA primers are specific for A. vitis and target a gene coding for polygalacturonase located on the bacterial chromosome (Eastwell et al. 1995). However, the results of this study indicate that success of a ddPCR assay may be gene or primer specific and require optimization steps for each new target gene, because the assay did not work well when primer pair virD2 was used.

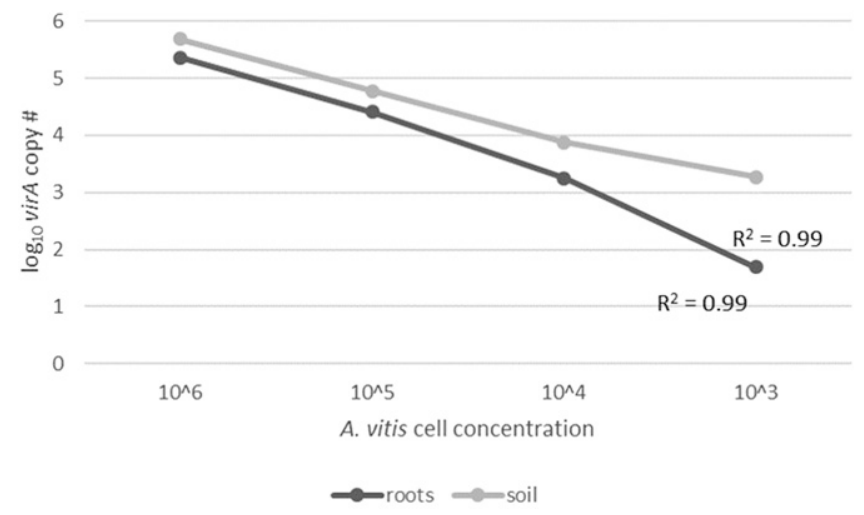

Fig. 4. Quantification limit of the virA droplet digital polymerase chain reaction assay in roots and vineyard soil spiked with serial dilutions of Agrobacterium vitis CG47 cells. Data points represent the mean of three separate experiments. The lower limit of the linear range of the assay determined the quantification limit (1,000 cells for roots and soil).

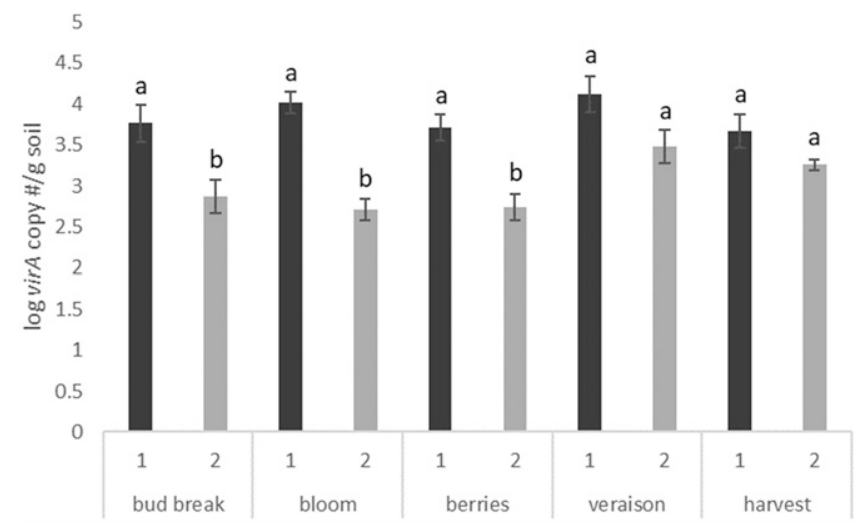

Fig. 5. Log virA copy numbers per gram of rhizosphere soil. 1: vineyard 1, 2: vineyard 2. Soil was sampled at five grapevine growth stages in 2017; bud break: 2 May, bloom: 20 June, berries: 6 July, veraison: 28 August, harvest 10 October. Bars indicate standard error of the mean $(n=6)$. Different lower case letters within one growth stage indicate differences of least squares means using the Welch's $t$ test at $P<0.05$.
Detection limits were compared with the study conducted by Johnson et al. (2013). The virA ddPCR assay was 10-fold more sensitive compared with the virD2 $\mathrm{qPCR}$ MCH assay when purified $A$. vitis DNA was used. However, MCH detected as few as 10 cells when grape tissue was inoculated, while the virA ddPCR assay was able to detect 100 cells when roots were spiked with $A$. vitis cells. Because PCR-inhibitory substances that might have been coisolated from grapevine roots are diluted with ddPCR, they should only play a minor role and not affect the detection limit greatly. However, in qPCR, inhibitory substances may lead to a reduced assay efficiency which, in turn, can lead to a quantification bias (Kim et al. 2014). Therefore, if the goal of a future study is to detect very few A. vitis cells, $\mathrm{MCH}$ is favorable. If quantification is desired, the ddPCR assay is the method of choice. However, both methods will require more evaluation with naturally contaminated plants to determine their applicability under different scenarios. Increased sensitivity of ddPCR assays over qPCR assays has been reported in other studies where environmental DNA samples were used (Cavé et al. 2016; Kim et al. 2014) but others report comparable sensitivities (Blaya et al. 2016; Dreo et al. 2014). A major advantage of ddPCR over qPCR is the ability for absolute quantification, without the need for an external standard. This greatly facilitates comparability of data and experimental setup where standards are not readily available. However, ddPCR requires more time to set up, compared with qPCR. This is because droplets need to be generated and read, in addition to running the PCR cycles. Cost per well is about 3.9 times higher for ddPCR compared with qPCR. However, in qPCR, each sample has to be run in triplicate and the cost of the standards needs to be included in the calculation. This makes ddPCR generally more cost effective but exact numbers depend on the individual set-up of the reactions (numbers of samples, points on the standard curve, and number of replicates).

Because of the unequal distribution of $A$. vitis in dormant canes (Johnson et al. 2016), cuttings from the same plant in an infected nursery mother block will likely have varying bacterial numbers, as indicated by the variation of virA copy numbers in the replicate test samples. Because of this and the uncertainty of $A$. vitis location within roots, it is important to test a sufficient number of samples and to follow a root sampling procedure similar to the one developed in this study.

Although this study mainly describes a novel methodology and only a limited number of nurseries was tested via the virA assay, results indicate that the plants with the highest numbers of $A$. vitis were originating from Californian nurseries. The same variety (Chardonnay) on the same rootstock (3309) harbored 300 times more A. vitis cells when originating from California compared with Ontario. Conditions in California are not conducive to crown gall development because of a warmer climate with no winter freezing. Plants in grapevine mother blocks may be systemically infected with $A$. vitis but do not develop disease. In addition, other economically important grapevine pathogens such as viruses (Grapevine leafroll associated viruses or Grapevine red blotch virus) or bacteria (Xylella fastidiosa) are of greater importance in California, leading to different testing foci. Because $A$. vitis is a nonregulated plant pathogen, no testing is required before shipment. However, plants imported to Canada or to other cool-climate grape-growing regions in the United States such as New York and Washington State are at risk to develop crown gall disease upon planting. Thus, it is important to produce crown gall-free nursery stock and test purchased material with the newly developed sensitive methodologies such as $\mathrm{MCH}$ and ddPCR before planting. It is also important to emphasize that results cannot be generalized because only six nurseries were compared in this study. A future study should increase the number of nurseries tested in varying

Table 3. VirA copy numbers per $0.25 \mathrm{~g}$ of soil in vineyard 1 and 2 over the 2017 growing season ${ }^{\mathrm{z}}$

\begin{tabular}{lccccc}
\hline Vineyard & Bud break & Bloom & Berries & Veraison & Harvest \\
\hline 1 & $8,803( \pm 7,165)$ & $12,115( \pm 7,000)$ & $7,095( \pm 7,128)$ & $22,068( \pm 24,915)$ & $8,731( \pm 11,826)$ \\
2 & $1,047( \pm 673)$ & $614( \pm(423)$ & $745( \pm 533)$ & $2,328( \pm 1,590)$ & $1,922( \pm 655)$ \\
\hline
\end{tabular}

${ }^{\mathrm{z}}$ Numbers are means $(n=6)$ followed by the standard deviation. 
regions worldwide in order to draw a potential significant correlation between nursery material origin and $A$. vitis abundance.

Indexing for presence or absence of the pathogen does not predict whether disease will occur in the vineyard. Disease development depends on pathogen density in the plant and environmental conditions that can lead to vine injuries, such as freezing temperatures (Burr et al. 1998). Monitoring for galls in the year following planting indicated that a high $A$. vitis concentration may be required to cause the development of galls. In addition, plants from the same shipment as sample ID 8 did develop galls in the vineyard but plants from sample ID 9 did not, although the virA copy numbers found in the nursery stock were high. The sample ID 8 vineyard was located at a site with a higher elevation but distant from Okanagan Lake, which moderates temperature. The sample ID 9 vineyard was located on a hill beside the lake, which allowed for better soil drainage and likely reduced freeze injuries. Therefore, many factors in addition to the A. vitis concentration of nursery stock, such as site characteristics, management practices, and environmental conditions, need to be taken into account.

Because bacteria on decaying necrotic grapevine roots in soil represent a second major source of $A$. vitis inoculum for replanted grapevines (Burr et al. 1998; Süle et al. 1995), the ddPCR assay was expanded to quantify the $A$. vitis soil population. Few reports on $A$. vitis abundance in soil exist (Bishop et al. 1988; Burr et al. 1987, 1995; Pu and Goodman 1993). Bacteria are present in higher numbers in soil associated with grapevine roots than with nonhost rhizospheres (Bishop et al. 1988) and population density has been estimated by dilution plating to be 9,000 CFU/g of soil (Pu and Goodman 1993) and between $10^{3}$ to $10^{7} \mathrm{CFU} / \mathrm{g}$ of soil (Burr et al. 1987) in vineyards with crown gall symptoms. We found numbers of up to 64,000 virA copies/g of soil, with higher numbers consistently present in the older vineyard. Because both vineyards are planted with Chardonnay from the same nursery, grown on land with no previous grapevines and undergoing similar management strategies, we hypothesize that nursery material was infected with $A$. vitis before planting and that abundance of $A$. vitis in rhizosphere soil depends on age of the vineyard. In an older vineyard, more roots may decay and release bacteria into soil. In order to draw a significant correlation between vineyard age and $A$. vitis population in soil, and to recommend removal of grapevines at the onset of gall symptoms to prevent soil contamination, further studies are required, because the current one only tested a 5- and a 3-year-old vineyard.

Grapevine growth stage did not have an effect on A. vitis abundance in soil. This is in contrast to the $A$. vitis population within grapevines, where a seasonal effect has been reported $(\mathrm{Pu}$ and Goodman 1993). The study reported detection of A. vitis in 32 and $25 \%$ of plants, 2 and 3 years after planting, respectively, when sampling occurred in April. Sampling in fall (October, November, or December) did not result in A. vitis recovery. Soil likely serves as primary inoculum for roots of healthy grapevines but roots of mature grapevines may serve as a reservoir of bacteria, allowing translocation of $A$. vitis through xylem sap pressure into trunk and canes in spring, as previously proposed (Pu and Goodman 1993).

Although the results of this study are based on a 1-year survey, an interesting observation was that the A. vitis abundance in soil was correlated with the soil $\mathrm{C} / \mathrm{N}$ ratio, with a high $\mathrm{C} / \mathrm{N}$ ratio resulting in fewer bacteria. A promising future management strategy may include application of soil amendments with a high $\mathrm{C} / \mathrm{N}$ ratio such as bark wood mulch and compost; however, further studies are needed.

A potential application of the ddPCR assay lies within a national clean plant program to ensure that only healthy planting material is imported. In Canada, high numbers of plants are imported for the fast-growing wine industry from certified nurseries in France, Germany, and the United States. However, plants are not tested for crown gall because $A$. vitis is a nonregulated grape pathogen and sensitive methodologies for crown gall testing were lacking until recently. The ddPCR assay developed here can reduce the time needed to screen grapevine stock for $A$. vitis abundance because the assay allows for quantification within 1 to 2 days, making efficient testing of high numbers of samples possible. Other methodologies such as callusing of cuttings followed by plating on semiselective media take 6 weeks for completion (Johnson et al. 2013). Pruning an excessive grapevine root system before planting is a standard procedure done by growers; thus, the ddPCR assay can be regarded as nondestructive to the plant. However, a negative test result does not necessarily indicate that no bacteria are present in the rootstock or scion. Another application of the ddPCR assay could be for testing plants and soil in varying stages of the propagation process in grapevine nurseries. This could lead to the identification of the initial source of $A$. vitis or the stage of propagation where the infection occurs. Based on the results, nurseries could improve sanitation management within the propagation process.

Testing of nursery stock and vineyard soil via ddPCR prior to vineyard establishment can ensure that only uncontaminated grapevine stock is planted into healthy soil. Other continuing studies should include the determination of nursery stock and vineyard soil A. vitis abundance threshold, in order to predict disease occurrence and to facilitate disease management.

\section{Acknowledgments}

We thank local wineries for the donation of grapevine nursery stock and permission to sample vineyard soil; Agriculture and Agri-Food Canada for the A. vitis CG47 isolate; T. Burr (Cornell University) and J. R. Úrbez-Torres (Summerland Research and Development Centre) for scientific advice and reviewing the manuscript; M. Hart (University of British Columbia [UBC]-Okanagan) for use of ddPCR equipment; S. Poojari and P. Munro (Summerland Research and Development Centre) for providing grape seedlings and cherry roots; M. Larrabee (UBCOkanagan) for help with R; and R. Reade, M. Walker, J. Boulé, and D. O'Gorman (Summerland Research and Development Centre) for help throughout the project

\section{Literature Cited}

Bazzi, C., Piazza, C., and Burr, T. J. 1987. Detection of Agrobacterium tumefaciens in grapevine cuttings. 1. EPPO Bull. 17:105-112.

Bertani, G. 1951. Studies on lysogenesis I.: The mode of phage liberation by lysogenic Escherichia coli. J. Bacteriol. 62:293-300.

Bini, F., Geider, K., and Bazzi, C. 2008. Detection of Agrobacterium vitis by PCR using novel virD2 gene-specific primers that discriminate two subgroups. Eur. J. Plant Pathol. 122:403-411.

Bishop, A. L., Burr, T. J., Mittak, V. L., and Katz, B. H. 1989. A monoclonal antibody specific to Agrobacterium tumefaciens biovar 3 and its utilization for indexing grapevine propagation material. Phytopathology 79:995-998.

Bishop, A. L., Katz, B. H., and Burr, T. J. 1988. Infection of grapevines by soilborne Agrobacterium tumefaciens biovar 3 and population dynamics in host and nonhost rhizospheres. Phytopathology 78:945-948.

Blaya, J., Lloret, E., Santísima-Trinidad, A. B., Ros, M., and Pascual, J. A. 2016. Molecular methods (digital PCR and real-time PCR) for the quantification of low copy DNA of Phytophthora nicotianae in environmental samples. Pest Manage. Sci. 72:747-753

Burr, T. J., Bazzi, C., Süle, S., and Otten, L. 1998. Crown gall of grape: Biology of Agrobacterium vitis and the development of disease control strategies. Plant Dis. $82: 1288-1297$.

Burr, T. J., Katz, B. H., and Bishop, A. L. 1987. Populations of Agrobacterium in vineyard and nonvineyard soils and grape roots in vineyards and nurseries. Plant Dis. 71:617-620.

Burr, T. J., Ophel, K., Katz, B. H., and Kerr, A. 1989. Effect of hot water treatment on systemic Agrobacterium tumefaciens biovar 3 in dormant grape cuttings. Plant Dis. 73:242-245.

Burr, T. J., and Otten, L. 1999. Crown gall of grape: Biology and disease management. Annu. Rev. Phytopathol. 37:53-80.

Burr, T. J., Reid, C. L., Splittstoesser, D. F., and Yoshimura, M. 1996. Effect of heat treatments on grape bud mortality and survival of Agrobacterium vitis in vitro and in dormant grape cuttings. Am. J. Enol. Vitic. 47:119-123.

Burr, T. J., Reid, C. L., Yoshimura, M., Momol, E. A., and Bazzi, C. 1995. Survival and tumorigenicity of Agrobacterium vitis in living and decaying grape roots and canes in soil. Plant Dis. 79:677-682.

Cavé, L., Brothier, E., Abrouk, D., Bouda, P. S., Hien, E., and Nazaret, S. 2016. Efficiency and sensitivity of the digital droplet PCR for the quantification of antibiotic resistance genes in soils and organic residues. Appl. Microbiol. Biotechnol. 100:10597-10608.

Dreo, T., Pirc, M., Ramšak, Ž., Pavšič, J., Milavec, M., Žel, J., and Gruden, K 2014. Optimising droplet digital PCR analysis approaches for detection and quantification of bacteria: A case study of fire blight and potato brown rot. Anal. Bioanal. Chem. 406:6513-6528.

Eastwell, K. C., Willis, L. G., and Cavileer, T. D. 1995. A rapid and sensitive method to detect Agrobacterium vitis in grapevine cuttings using the polymerase chain reaction. Plant Dis. 79:822-827.

Hindson, B. J., Ness, K. D., Masquelier, D. A., Belgrader, P., Heredia, N. J., Makarewicz, A. J., Bright, I. J., Lucero, M. Y., Hiddessen, A. L., and Legler, 
T. C. 2011. High-throughput droplet digital PCR system for absolute quantitation of DNA copy number. Anal. Chem. 83:8604-8610.

Johnson, K. L., Cronin, H., Reid, C. L., and Burr, T. J. 2016. Distribution of Agrobacterium vitis in grapevines and its relevance to pathogen elimination. Plant Dis. 100:791-796.

Johnson, K. L., Zheng, D., Kaewnum, S., Reid, C. L., and Burr, T. 2013. Development of a magnetic capture hybridization real-time PCR assay for detection of tumorigenic Agrobacterium vitis in grapevines. Phytopathology 103:633-640.

Kim, T. G., Jeong, S. Y., and Cho, K. S. 2014. Comparison of droplet digital PCR and quantitative real-time PCR for examining population dynamics of bacteria in soil. Appl. Microbiol. Biotechnol. 98:6105-6113.

Lehoczky, J. 1971. Further evidences concerning the systemic spreading of Agrobacterium tumefaciens in the vascular system of grapevines. Vitis 10:215-221.

Ophel, K., and Kerr, A. 1990. Agrobacterium vitis sp. nov. for strains of Agrobacterium biovar 3 from grapevines. Int. J. Syst. Evol. Microbiol. 40:236-241.

Orel, D. C., Reid, C. L., Fuchs, M., and Burr, T. J. 2017. Identifying Environmental Sources of Agrobacterium vitis in vineyards and wild grapevines. Am. J. Enol. Vitic. 68:213-217.

Otten, L., Ruffray, P., Momol, E. A., Momol, M. T., and Burr, T. J. 1996. Phylogenetic relationships between Agrobacterium vitis isolates and their $\mathrm{Ti}$ plasmids. Mol. Plant-Microbe Interact. 9:782-786.
Peduto, F., Marchi, G., and Surico, G. 2010. Indexing Agrobacterium vitis in asymptomatic grapevine propagation material by two nested PCR assays. Am. J. Enol. Vitic. 61:102-112.

Pu, X.-A., and Goodman, R. N. 1993. Effects of fumigation and biological control on infection of indexed crown gall free grape plants. Am. J. Enol. Vitic. 44: 241-248.

Puławska, J., and Sobiczewski, P. 2005. Development of a semi-nested PCR based method for sensitive detection of tumorigenic Agrobacterium in soil. J. Appl. Microbiol. 98:710-721.

Schroth, M. N., McCain, A. H., Foott, J. H., and Huisman, O. C. 1988. Reduction in yield and vigor of grapevine caused by crown gall disease. Plant Dis. 72 241-246.

Stachel, S. E., and Zambryski, P. C. 1986. VirA and virG control the plant-induced activation of the T-DNA transfer process of $A$ tumefaciens. Cell 46:325-333.

Stewart, E. L., and Wenner, N. G. 2004. Grapevine decline in Pennsylvania and New York. Wine East 32:12-21.

Süle, S., Lehoczky, J., Jenser, G., Nagy, P., and Burr, T. J. 1995. Infection of grapevine roots by Agrobacterium vitis and Meloidogyne hapla. J. Phytopathol. 143:169-171.

Wise, A. A., and Binns, A. N. 2016. The receiver of the Agrobacterium tumefaciens VirA histidine kinase forms a stable interaction with VirG to activate virulence gene expression. Front. Microbiol. 6:1546. 